\title{
PLUTONIUM UTILIZATION PROGRAM: PRTR IRRADIATION PLANS
}

M. D. FRESHLEY, R. E. SHARP, and R. E. SKAVDAHL

\section{DEVELOPMENT REPORT}

$$
\text { AUGUST, } 1966
$$

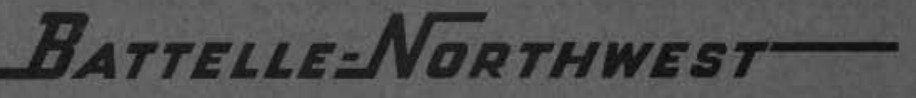

BATTELLE MEMORIAL INSTITUTE / PACIFIC NORTHWEST LABORATORY 


\section{LEGAL NOTICE}

This report was prepared as an account of Government sponsored work. Neither the United States, nor the Commission, nor any person acting on behalf of the Commission:

A. Makes any warranty or representation, expressed or implied, with respect to the accuracy, completeness, or usefulness of the information contained in this report, or that the use of any information, apparatus, method, or process disclosed in this report may not infringe privately owned rights; or

B. Assumes any liabilities with respect to the use of, or for damages resulting from the use of any information, apparatus, method, or process disclosed in this report.

As used in the above, "person acting on behalf of the Commission" includes any employee or contractor of the Commission, or employee of such contractor, to the extent that such employee or contractor of the Commission, or employee of such contractor prepares, disseminates, or provides access to, any information pursuant to his employment or contract with the Commission, or his employment with such contractor.

\section{PACIFIC NORTHWEST LABORATORY \\ RICHLAND, WASHINGTON \\ operated by \\ BATTELLE MEMORIAL INSTITUTE}

for the

UNITED STATES ATOMIC ENERGY COMMISSION UNDER CONTRACT AT(45-1)-1830 
BNWL-314

UC-80, Reactor Technology

\section{PLUTONIUM UTILIZATION PROGRAM:}

PRTR IRRADIATION PLANS

by

M. D. Freshley

R. E. Sharp

R. E. Skavdahl

Fuel Element Design and Evaluation Unit Materials Department

August, 1966

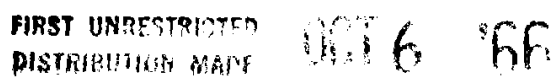

PACIFIC NORTHWEST LABORATORY

RICHLAND, WASHINGTON 
TABLE OF CONTENTS

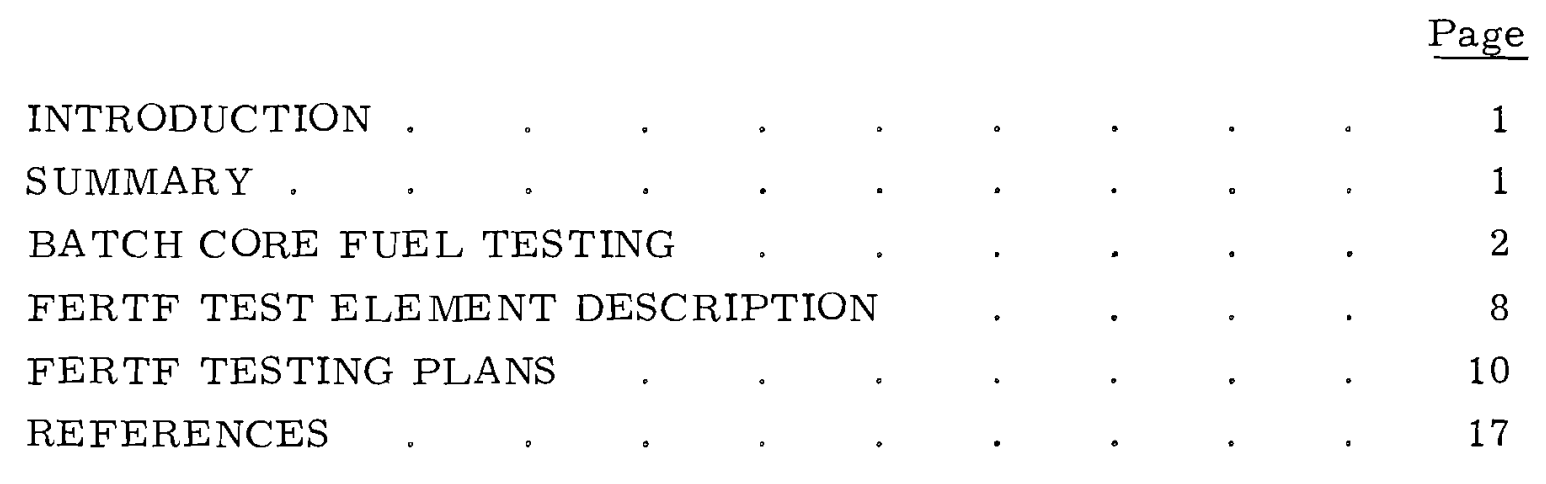

\section{FIGURES}

1 PRTR High Power Density Nineteen-Rod Cluster Fuel Element . . . . . . . 4

2 FERTF Test Element Basket Assembly • • . . . 9

\section{TABLES}

I Summary of Irradiated Fuel Rods . . . . . . 3

II Experimental Elements to be Irradiated in the Periphery of the PRTR During the Batch Core Experiment . . . . . . . 47

III Disposition of Individual Fuel Rods for $20 \mathrm{~kW} / \mathrm{ft}$ Test Series 12

IV Disposition of Individual Fuel Rods for $24 \mathrm{~kW} / \mathrm{ft}$ Test Series 13

$\mathrm{V}$ Disposition of Individual Fuel Rods for $28 \mathrm{~kW} / \mathrm{ft}$ Test Series 15 


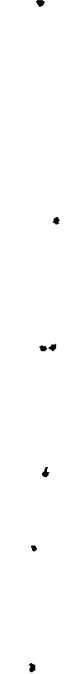




\section{INTRODUCTION}

This report details the PRTR irradiation program outlined in the FY-1967 through FY-1970 Plutonium Utilization Program (PUP) document. This plan of action is reported in recognition of the multiple goals and strong interaction among various parts of the overall Plutonium Utilization Program. Many of the tests outlined in this plan will be conducted under relatively unexplored conditions. An experimental program of sequential nature (as outlined herein) is subject to change based on accumulation of experimental results and other new knowledge obtained earlier in the program. An existing procedure assures that program changes are made only after full consideration of the interactions with all other facets of the Batch Core Experiment.

One of the principal objectives of the Fuels Development portion of the Plutonium Utilization Program is to determine whether plutonium enriched oxide fuels are limited to powers and/or exposures significantly less than those attainable with enriched uranium oxide fueis. To accomplish these objectives: fuel element irradiation tests will be conducted in the High Power Density (HPD) core* of the Plutonium Recycle Test Reactor (PRTR) ${ }^{(3)}$ during the Batch Core Experiment and in the Fuel Element Rupture Test Facility (FERTF) ${ }^{(4)}$ of PRTR. Individual fuel rod reactivity measurements will be made in the Plutonium Recycle Critical Facility (PRCF). (5) Supplementary tests wili be run in the MTR/ETR and TREAT facilities, but will not be described in this plan.

\section{SUMMARY}

The Batch Core Experiment in PRTR is a large-scale burnup experiment that will supply information on operating characteristics of a $\mathrm{UO}_{2}-$ $\mathrm{PuO}_{2}$ fueled reactor. The operating conditions are typical of power reactor conditions. The physics and fuels testing objectives of the Batch Core experiment are closely related. The experiment will provide statistically significant

* The High Power Density (HPD) core is a loading that increases the average power density of the PRTR above previous core loadings by shortening the fuel elements and reducing the total number of fueled tubes. The core configuration, power level, power density, etc., will depend on the specific experiment to be performed. 
performance data on vibrationally compacted mixed-oxide fuel elements. These elements operate with maximum fuel temperatures as high as those in proposed commercial power reactors to maximum fuel element burnups of 13,000 MWd/MT fuel. Operation under these conditions will give needed information to commercial power reactor operators about the basic feasibility of operating full core loadings of plutonium-bearing fuels.

Concurrent with the Batch Core Experiment, irradiation testing of nondefected and deliberately defected fuel rods will be conducted in the FERTF at maximum rod powers to $28 \mathrm{~kW} / \mathrm{ft}$, with fuel temperatures above melting. Since a commercial power reactor must accommodate the presence of in-core "leaker" fuel elements, a study of the defect behavior of oxide fuel rods constitutes an important part of the fuel element testing program in the FERTF. Another important objective of the program is to provide a direct comparison of the irradiation behavior of pelleted and vibrationally compacted (nominally 85 to $87 \%$ TD) oxide fuel rods operating under high performance conditions (maximum linear rod powers in the range of 20 to $28 \mathrm{~kW} / \mathrm{ft}$, with significant fuel melting).

Table I summarizes the fuel rod types and burnups which will have been irradiated and examined in the 20,24 , and $28 \mathrm{~kW} / \mathrm{ft}$ test series in FERTF.

\section{BATCH CORE FUEL TESTING}

The major fuels development objective of the Batch Core Experiment is to obtain statistical irradiation behavior data on $\mathrm{UO}_{2}-\mathrm{PuO}_{2}$ fuel rods operated at significant rod power generations. A second important objective is to assure continued safe operation of PRTR by constant and careful fuel element surveillance.

The Batch Core Experiment involves operation of the PRTR loaded with 66 fuel elements (Figure 1) containing about 2.3 tons of $\mathrm{UO}_{2}-2 \mathrm{wt} \%$ $\mathrm{PuO}_{2}$ fuel. The central 54 elements will be used in a series of critical experiments at various stages of burnup to determine the nuclear properties 


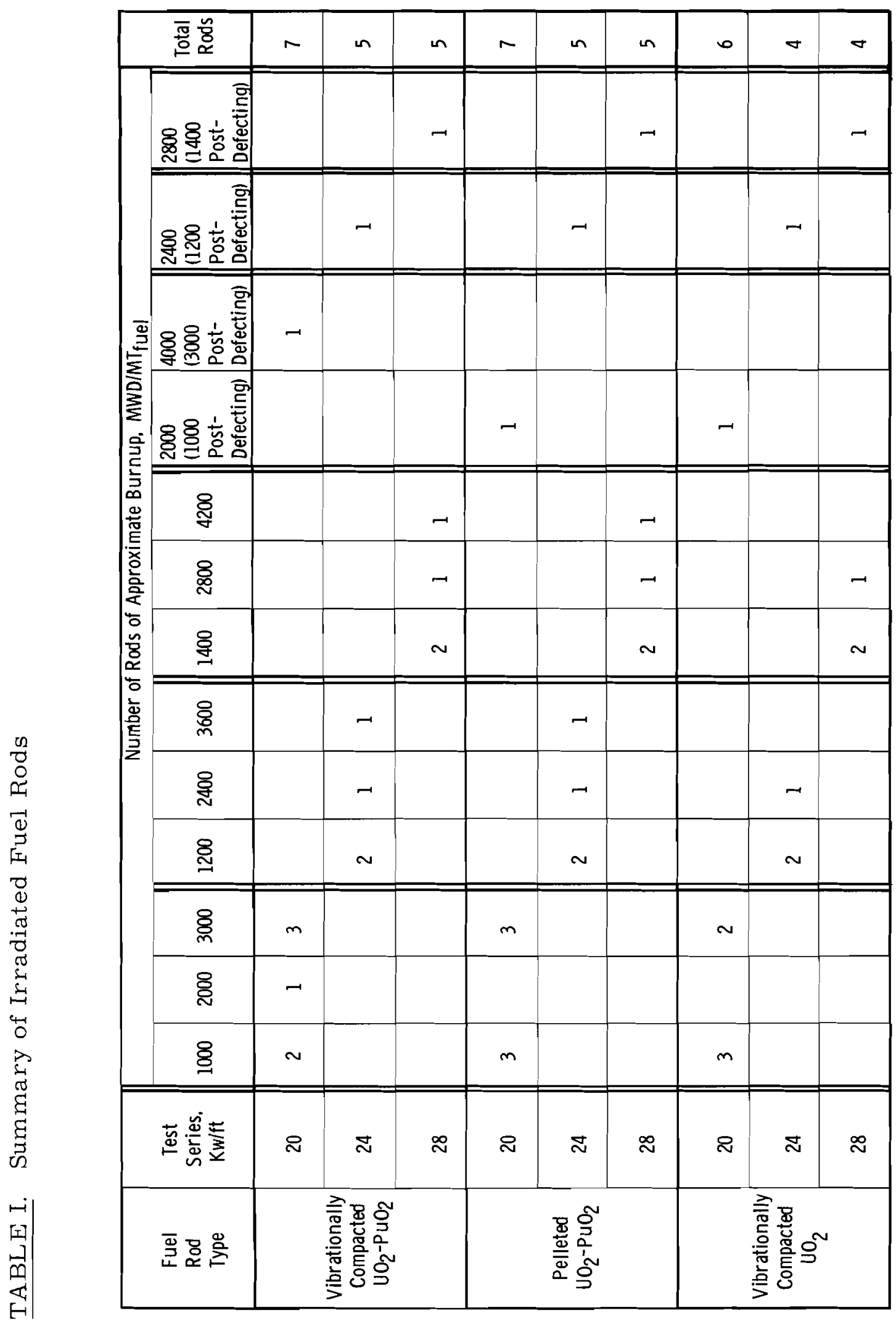




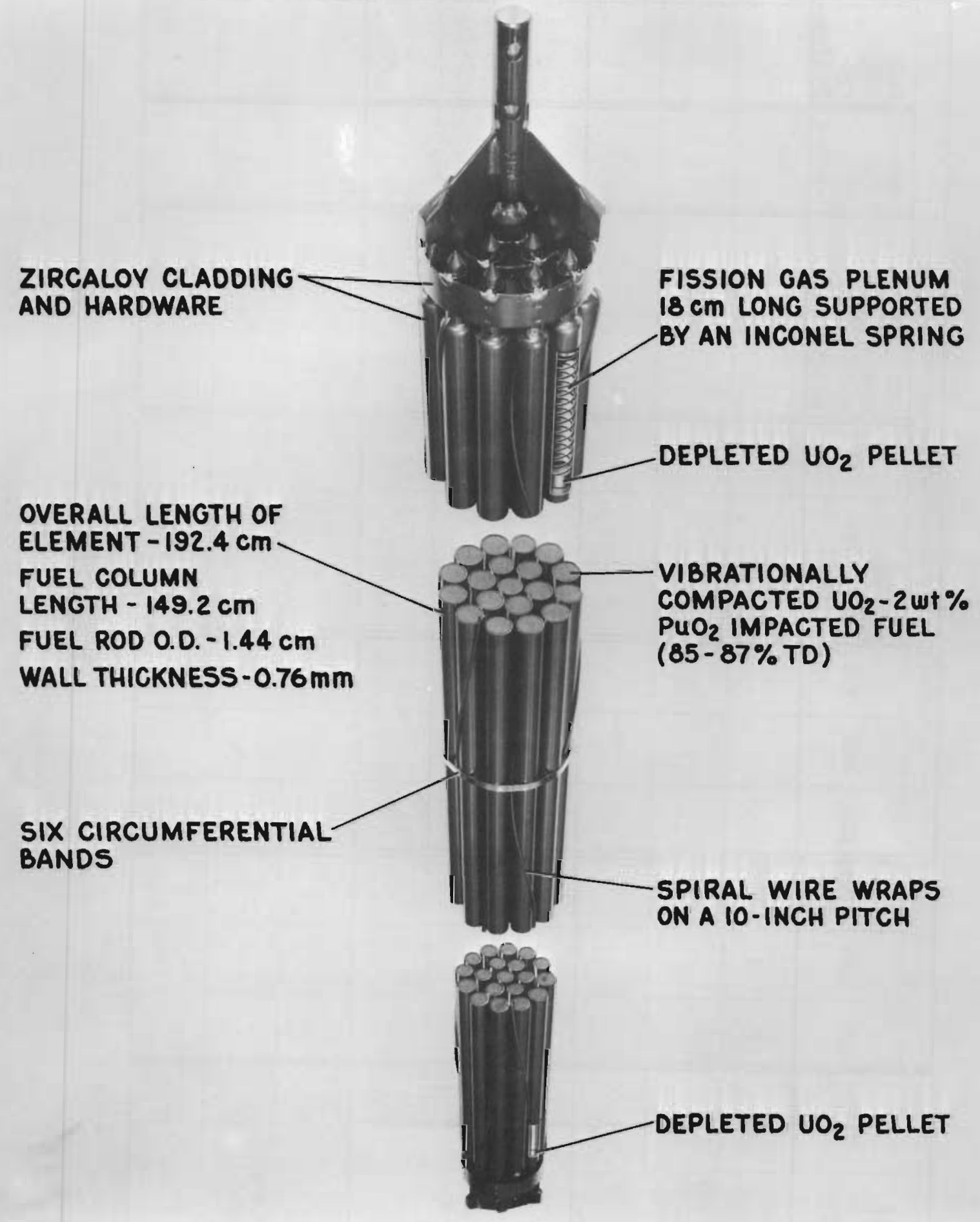

FIGURE 1. PRTR High Power Density Nineteen-Rod Cluster Fuel Element 
of the fuel as a function of burnup. Twelve elements constitute a surrounding buffer zone which will also serve as a source of replacement rods and elements, The Batch Core Experiment will continue to a total average core burnup of $10,000 \mathrm{MWd} / \mathrm{MT}_{\text {fuel }}$. These burnups will be accumulated at maximum linear rod powers to $20 \mathrm{~kW} / \mathrm{ft}$, which will produce a maximum local burnup of approximately 20,000 $\mathrm{MWd} / \mathrm{MT}_{\text {fuel, }}$, with maximum fuel temperatures $\left(2600\right.$ to $\left.2800^{\circ} \mathrm{C}\right)$ near melting.

Several important features of fuel behavior reilated to the use of plutonium enrichment will be investigated during the Batch Core Experiment. These include fuel relocation or slumping and plutonium migration or segregation which might lead to operating problems in a power reactor if manifest in a significant number of elements. Plutonium additions might affect fuel plasticity and long-term creep and, consequently, fuel relocation and rod sweiling. Plutonium additions might also affect the thermal conductivity of the fuel and, hence, the operating temperatures and fission gas release characteristics. Long-term corrosion behavior, dimensional stability, and fission product migration and fuel structures will also be studied during the Batch Core Experiment.

An important aspect of the Batch Core Experiment will be an evaiuation of the comparative performance of packed particle and pellet fuels. Although the majority of the 66 fuel elements in the core will be of the packed-powder variety, two elements assembled from commercially procured peilet fuel rods as well as several single pellet rods incorporated into several packed particle fuel elements will be irradiated in the PRTR core. Some of these irradiated rods will be used for special tests such as subsequent irradiation in the FERTF, defect testing in the FERTF, experiments in the PRCF, and transient testing in TREAT reactor.

Two rods in each of two vibrationaliy compacted elements located in the basic 54 element core will be instrumented to measure internal gas pressure and plenum gas temperature during irradiation. This information is related to fuel rod design, evaluation of fuel performance, and an understanding of fission gas release behavior. 
Packed particle and pellet fuel rods will be removed from the core of the reactor at various exposure levels for postirradiation examination. The first rods will be removed for visual examination shortly after the maximum power generating condition of $20 \mathrm{~kW} / \mathrm{ft}$ has been achieved to detect changes in physical appearance. The short-term irradiation effects under Batch Core Experiment conditions will be evaluated during this examination. Other rods will be removed for destruction examination in conjunction with the removal of rods for the physics program; therefore, postirradiation examination expense will be minimized, and the amount of information resulting from the examination at various exposure levels will be greatly increased.

In addition to the destructive examination of fuel rods at various exposure levels, the irradiation behavior of a significant number (approximately 25) of fuel elements operated under Batch Core Experiment conditions will be monitored by underwater examination in the PRTR basin. The underwater surveiliance will also coincide with the shutdowns scheduled for physics purposes. Underwater examination provides information on the corrosion behavior of the Zircaloy clad fuel elements, wire wrap behavior, fretting behavior, crevice corrosion effects, behavior of the circumferential strip bands around the element, bearing surface or pad wear, and information on other gross irradiation effects.

Besides the irradiation of $66 \mathrm{HPD}$ elements in the Batch Core Experiment, special irradiation tests will be performed in the peripheral positions of the core. The se tests consist primarily of the continued irradiation of selected elements previously exposed in PRTR. Those elements planned for inclusion in peripheral positions at the start of the Batch Core Experiment are listed in Table II.

A FERTF Test Element will be irradiated in the periphery of the PRTR core during the Batch Core Experiment as a source of irradiated fuel rods for subsequent testing in the FERTF. Also, the peripheral positions will be used to irradiate fuel elements of advanced designs, such as the inverted cluster. 
TABLE II. Experimental Elements to be Irradiated in the Periphery of the PRTR During the Batch Core Experiment

Element

No.

6003

6005

6006

5224

5226

5227

5118

5142

5186

1037

6501

$6521 *$

Element to supply irradiated rods for the FERTF
Present Burnup MWd/MT fuel
4510

2520

2420

6920

5720

5820

10,200

8840

6510

8830

2690

0

0

$*$ Two of the nineteen rods in the $\mathrm{ThO}_{2}-\mathrm{PuO}_{2}$ element are instrumented to measure internal gas pressure and plenum gas temperature during irradiation. 


\section{FERTF TEST ELEMENT DESCRIPTION}

Fuel element irradiation testing, with the specially designed FERTF test element, is planned to begin in the FERTF near the start of the Batch Core Experiment. The in-reactor test section will be located in the center channel (\#1550) of the PRTR. The center channel location will permit testing of fuel elements at high specific power in the FERTF while other fuel and physics data are being obtained in the main core during the Batch Core Experiment.

The specially designed FERTF test element consists of a six-rod ring of standard replaceable high power density fuel rods (Mark I-R) enclosed in a protective basket tube.

The FERTF test element assembly is composed of a basket tube, fuel rod rack, and two end supports (Figure 2). Full length spacing ribs, on the basket tube, position the basket in the center of the pressure tube. The fuel rod rack, which can be removed from the basket assembly as an integral unit, has several spacer grids along its length that position and support the fuel rods while allowing independent expansion and contraction of individual rods. The center support of the fuel rod rack is utilized as a flux wire channel. The fuel rod rack is made of Zircaloy-2, while the end fittings and basket are made of stainless steel. Manipulations of the FERTF test element will be performed with the major axis of the element in a vertical position.

The different power generations for the various test series will be accomplished by adjusting the plutonium concentration of the fuel between 2 and 6 wt $\% \mathrm{PuO}_{2}$. Plutonium concentrations of the vibrationally compacted and the pellet-containing fuel will be adjusted to yield the same gross fissile atom density in the fuel rods for each test series. This will provide comparable power generations for the different fuel types within each test series.

While the plutonium concentration of the fuel is adjusted to achieve the desired power generations, the boron concentration of the stainless 


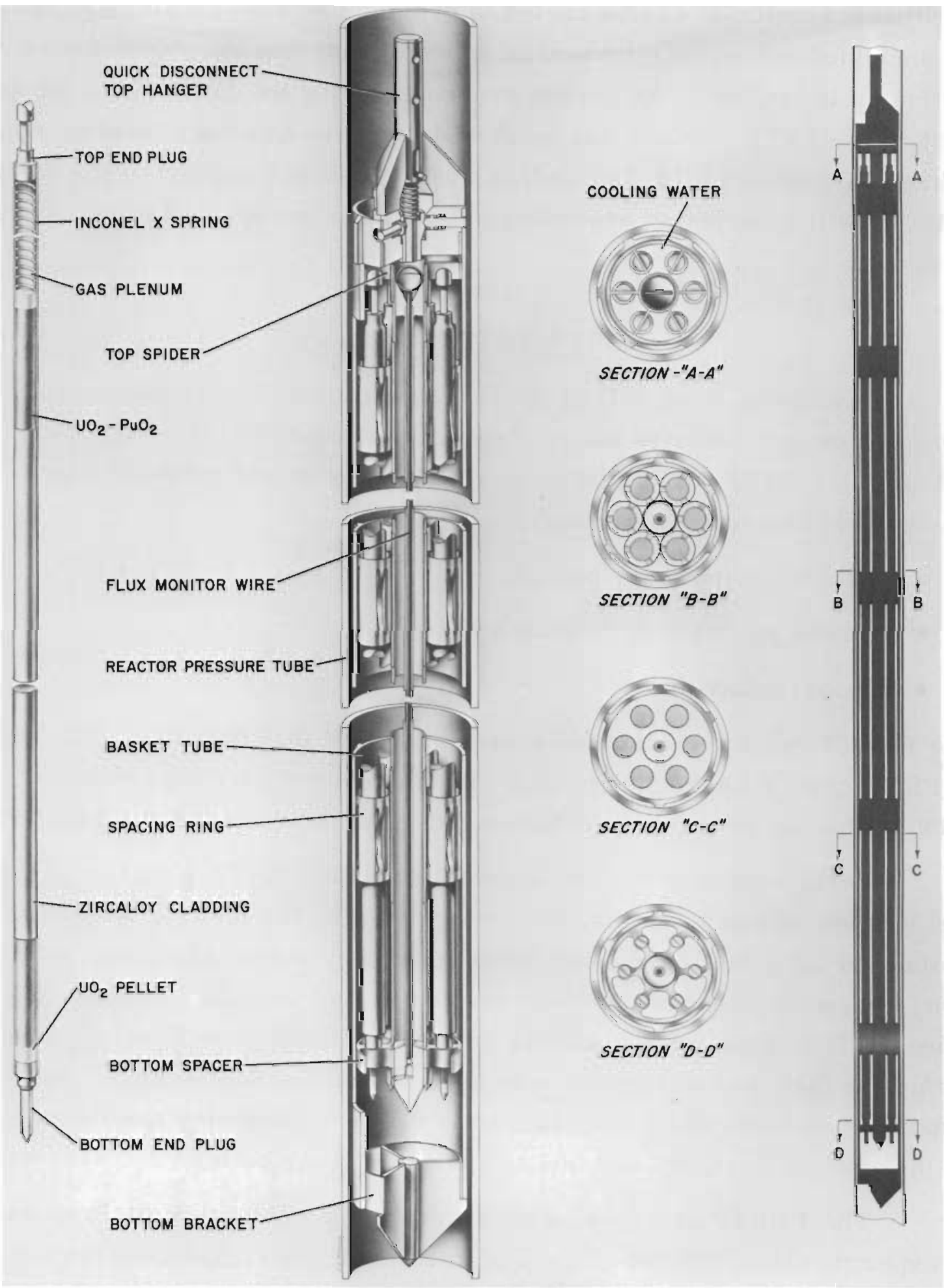

FIGURE 2. FERTF Test Element Basket Assembly 
steel basket material can be varied to provide increased fexibility. Boron will be added to the basket material to avoid reducing the plutonium concentration in the fuel. As burnup proceeds during the Batch Core Experiment, the FERTF neutron flux level will increase and the plutonium concentration of the FERTF fuel and/or the boron concentration of the basket material will be adjusted accordingly to achieve the desired experimental conditions.

\section{FERTF TESTING PLANS}

Irradiation tests will be performed on vibrationally compacted $\mathrm{UO}_{2}$, and on both pelleted and vibrationally compacted $\mathrm{UO}_{2}-\mathrm{PuO}_{2}$ fuel rods in the FERTF. The test program includes investigation of three particularly important parameters:

- Fuel form (powder, pellet),

- Power generation (20 to $28 \mathrm{~kW} / \mathrm{ft}$ ),

- Defect behavior.

The FERTF tests will also serve as a source of irradiated rods for use in PRCF and TREAT experiments. Rods previously irradiated in the PRTR core, as well as unirradiated rods, will be tested in the FERTF.

Performance data to be derived from the FERTF program include fuel washout characteristics, water-logging effects, fuel rod swelling, radial and axial fuel relocation, fission product and/or plutonium migration, plutonium segregation from the liquid, fuel volatility, fission gas release, fuel visosity as it affects mobility and ability to flow into cracks within the fuel, and convective mixing in the molten fuel region. Another important variable to be investigated is fuel stoichiometry and its effect on thermal conductivity and fuel temperature distribution.

The FERTF fuel testing program will be performed in three series of experiments conducted at nominal maximum linear rod powers of 20 , 24 , and $28 \mathrm{~kW} / \mathrm{ft}$. It is planned that the $20 \mathrm{~kW} / \mathrm{ft}$ series of experiments will consist of 7 operating cycles; whereas, the 24 and $28 \mathrm{~kW} / \mathrm{ft}$ test series 
will each consist of four operating cycles. A burnup of approximately $1000 \mathrm{MWd} / \mathrm{MT}$ is accumulated during each operating cycle at a maximum linear rod power of $20 \mathrm{~kW} / \mathrm{ft}$. Fuel rod exchanges will be made at the beginning of each irradiation cycle. The conduct of each series of experiments will be essentially the same, the main difference being the successively increased maximum rod power.

Along with the irradiation of $\mathrm{UO}_{2}-\mathrm{PuO}_{2}$ fuel rods, the experiments will include irradiation of vibrationally compacted enriched- $\mathrm{UO}_{2}$ fuel rods for comparative purposes (where appropriate).

The initial test series (Table III), which will be conducted at a maximum linear rod power of $20 \mathrm{~kW} / \mathrm{ft}$, is expected to produce maximum fuel temperatures $\left(2600\right.$ to $2800^{\circ} \mathrm{C}$ ) near melting in vibrationally compacted rods and temperatures below melting in pellet-containing rods. These initial irradiations will be conducted to evaluate irradiation performance and defect behavior of vibrationally compacted and pellet-containing $\mathrm{UO}_{2}$ $\mathrm{PuO}_{2}$ fuel rods operating under the maximum Batch Core Experiment conditions. This information will supplement that derived from the Batch Core Experiment. Investigation of the behavior of defected fuel rods operated at these conditions will be especially important because it will help determine the maximum permissible power level of PRTR while operating with a known defective fuel element in the main core. Fuel rods will be defected by drilling a 1/16 in. diam hole through the cladding at the axial position of maximum power generation.

Following the test series at a maximum rod power of $20 \mathrm{~kW} / \mathrm{ft}$, the next series of tests will be conducted at a maximum rod power of approximately $24 \mathrm{~kW} / \mathrm{ft}$ (Table IV). This power generation is expected to produce fuel melting in the vibrationally compacted rods and an incipient melting condition in the pellet-containing fuel rods.

It is possible that rods from the $24 \mathrm{~kW} / \mathrm{ft}$ test series will be placed in the PRTR core for continued irradiation at reduced linear rod powers. The purpose of such an experiment would be to investigate the effects of long exposure at reduced fuel temperatures on fuel structures formed under higher temperature conditions. 
TABLE III. Disposition of Individual Fuel Rods for $20 \mathrm{~kW} / \mathrm{ft}$ Test Series

\begin{tabular}{|c|c|c|c|c|c|c|c|c|c|c|c|c|c|}
\hline \multirow[b]{2}{*}{$\begin{array}{c}\text { Cycle } \\
\text { No. }\end{array}$} & \multirow[b]{2}{*}{ Event } & \multicolumn{8}{|c|}{ Approximate Fuel Rod Burnup Status, MWD/MT fuel } & \multirow{2}{*}{\begin{tabular}{|l|} 
Retained \\
in Test \\
Assembly \\
for use in \\
Next Cycle
\end{tabular}} & \multirow{2}{*}{$\begin{array}{l}\text { Placed in } \\
\text { Storage } \\
\text { Basin for } \\
\text { Future } \\
\text { Use } \\
\end{array}$} & \multirow{2}{*}{$\begin{array}{l}\text { Transferred } \\
\text { To Radiomet } \\
\text { for Post- } \\
\text { Irradiation } \\
\text { Examination }\end{array}$} & \multirow[b]{2}{*}{$\begin{array}{l}\text { Drill } \\
\text { Defect } \\
\text { Hole }\end{array}$} \\
\hline & & Unirrad. & 1000 & 2000 & 3000 & $\begin{array}{l}1000 \\
\text { at Time } \\
\text { of } \\
\text { Defecting }\end{array}$ & \begin{tabular}{|l|}
2000 \\
1000 \\
Post- \\
Defecting)
\end{tabular} & $\begin{array}{l}3000 \\
12000 \\
\text { Post- } \\
\text { Oefecting) }\end{array}$ & $\begin{array}{l}4000 \\
(3000 \\
\text { Post- } \\
\text { Defecting })\end{array}$ & & & & \\
\hline \multirow{3}{*}{1} & $\begin{array}{c}\text { Start } \\
\text { of Cycle }\end{array}$ & $\begin{array}{l}\text { (1) } 10 \\
\text { (2) } 2 \text { (1) }\end{array}$ & & & & & & & & & & & \\
\hline & $\begin{array}{l}\text { End } \\
\text { of Cycle }\end{array}$ & & $\begin{array}{l}\text { (1) } 1] \Delta \\
\text { (2) } 2 \mathrm{a} B\end{array}$ & & & & & & & & & \multirow[b]{2}{*}{ 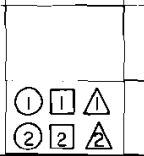 } & \\
\hline & $\begin{array}{c}\text { Disposition } \\
\text { of Rods }\end{array}$ & & & & & & & & & & & & \\
\hline \multirow{3}{*}{2} & $\begin{array}{c}\text { Start } \\
\text { of Cycle }\end{array}$ & 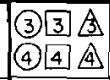 & & & & & & & & & & & \\
\hline & $\begin{array}{l}\text { End } \\
\text { of Cycle }\end{array}$ & & $\begin{array}{l}\text { (3) } \frac{3}{3} \\
\text { (4) } 4 \\
4\end{array}$ & & & & & & & & & & \\
\hline & $\begin{array}{c}\begin{array}{c}\text { Disposition } \\
\text { of Rods }\end{array} \\
\end{array}$ & & & & & & & & & (4) $\frac{4}{5} 4$ & 3 合 & & (3) \\
\hline \multirow{3}{*}{3} & $\begin{array}{c}\text { Start } \\
\text { of Cycle }\end{array}$ & (5) 5 & (4) 4 A & & & (3) & & & & & & & \\
\hline & $\begin{array}{l}\text { End } \\
\text { of Cycie }\end{array}$ & & (5) 5 & (4) 4.4 & & & (3) & & & & & & \\
\hline & $\begin{array}{c}\text { Disposition } \\
\text { of Rods }\end{array}$ & & & & & & & & & $\begin{array}{l}3 \\
(4) \\
(5)\end{array}$ & & & \\
\hline \multirow{3}{*}{4} & $\begin{array}{l}\text { Start } \\
\text { of Cycle }\end{array}$ & & (5) 5 & (4) 4. 4 & & & (3) & & & & & & \\
\hline & $\begin{array}{c}\text { End } \\
\text { of Cycle }\end{array}$ & & & (5) 5 & (4) 4 A & & & (3) & & & & & \\
\hline & $\begin{array}{c}\text { Disposition } \\
\text { of Rods }\end{array}$ & & & & & & & & & (3) (5) 5 & & (4) 4 4 & \\
\hline \multirow{3}{*}{5} & $\begin{array}{c}\text { Start } \\
\text { of Cycle }\end{array}$ & (6) 6 令 & & (5) 5 & & & & (3) & & & & & \\
\hline & $\begin{array}{c}\text { End } \\
\text { of Cycle }\end{array}$ & & (6) & & (5) 5 & & & & (3) & & & & \\
\hline & \begin{tabular}{|c|} 
Disposition \\
of Rods
\end{tabular} & & & & & & & & & (6) 6 D & & (5) 5 & 3 \\
\hline \multirow{3}{*}{6} & $\begin{array}{c}\text { Start } \\
\text { of Cycle }\end{array}$ & (7) 7 & (6) 6 , & & & 3 & & & & & & & \\
\hline & $\begin{array}{c}\text { End } \\
\text { of Cycle }\end{array}$ & & (7) 7 & (6) 6 S & & & 3 & & & & & & \\
\hline & $\begin{array}{c}\text { Disposition } \\
\text { of Rods }\end{array}$ & & & & & & & & & $\begin{array}{l}(7) \\
\text { (6) } 6\end{array}$ & & $\begin{array}{l}3 \\
7 \\
\end{array}$ & B \\
\hline \multirow{3}{*}{7} & $\begin{array}{c}\text { Start } \\
\text { of Cycle }\end{array}$ & $\therefore$ & (7) & (6) 6 令 & & 令 & & & & & & & \\
\hline & $\begin{array}{l}\text { End } \\
\text { of Cycie }\end{array}$ & & 合 & (7) & (6) 65 & & 争 & & & & & & \\
\hline & $\begin{array}{c}\text { Disposition } \\
\text { of Rods }\end{array}$ & & & & & & & & & & & (6) $6 \frac{\mathrm{A}}{\mathrm{A}}$ & \\
\hline
\end{tabular}

NOTES:

1. The FERTF Test Element Assembly Contains 6 Individually Replaceable Fuel Rods.

2. $20 \mathrm{Kw} / \mathrm{ft}$ is the Planned Maximum Local Linear Rod Power (Axial Peak-to-Average Power Ratio $=1.29$ ).

3. (N) Represents the $\mathrm{N}^{\mathrm{th}}$ Vibrationally Compacted $\mathrm{UO}_{2}$-PuO2 $\mathrm{Fuel}$ Rod in this Test Series.

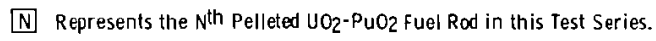

A Represents the Nth Vibrationally Compacted $\mathrm{UO}_{2}$ fuel Rod in this Test Series.

4. Each Irradiation Cycle is Assumed to be 25 operating Days.

5. Each Irradiation Cycle is Assumed to Result in an Incremental Burnup of $1000 \mathrm{MwD} / \mathrm{MT}$ fuel at the Position of $20 \mathrm{Kw} / \mathrm{Ft}$ Linear Rod Power.

6. Fuel Rods are Defected by Drilling a 1/16" Diameter Hole Through the Zr-2 cladding at the Position of $20 \mathrm{Kw} / \mathrm{Ft}$ Linear Rod Power. 
TABLE IV. Disposition of Individual Fuel Rods for $24 \mathrm{~kW} / \mathrm{ft}$ Test Series

\begin{tabular}{|c|c|c|c|c|c|c|c|c|c|c|c|}
\hline \multirow[b]{2}{*}{$\begin{array}{c}\text { Cycle } \\
\text { No. }\end{array}$} & \multirow[b]{2}{*}{ Event } & \multicolumn{6}{|c|}{ Approximate Fuel Rod Burnup Status, MWD/MT fuel } & \multirow{2}{*}{$\begin{array}{l}\text { Retained } \\
\text { in Test } \\
\text { Assembly } \\
\text { for use in } \\
\text { Next Cycle }\end{array}$} & \multirow{2}{*}{\begin{tabular}{|l|} 
Placed in \\
Storage \\
Basin for \\
Future \\
Use \\
\end{tabular}} & \multirow{2}{*}{\begin{tabular}{l|} 
Transferred \\
to Radiomet \\
for Post- \\
Irradiation \\
Examination
\end{tabular}} & \multirow[b]{2}{*}{$\begin{array}{l}\text { Drill } \\
\text { Defect } \\
\text { Hole }\end{array}$} \\
\hline & & | Unirrad. & 1200 & 2400 & 3600 & \begin{tabular}{|l|}
1200 \\
at Time \\
of \\
Defecting
\end{tabular} & $\begin{array}{l}2400 \\
(1200 \\
\text { Post- } \\
\text { Defecting) }\end{array}$ & & & & \\
\hline \multirow{3}{*}{8} & $\begin{array}{c}\text { Start } \\
\text { of Cycle }\end{array}$ & $\begin{array}{l}\text { (1) } 110 \\
\text { (2) } 20\end{array}$ & & & & & & & & & \\
\hline & $\begin{array}{l}\text { End } \\
\text { of Cycle }\end{array}$ & & $\begin{array}{l}\text { (1) } 1 \text { 1 } \\
\text { (2) } 2 \mathrm{~A}\end{array}$ & & & & & & & & \\
\hline & $\begin{array}{c}\text { Disposition } \\
\text { of Rods }\end{array}$ & & & & & & & & 20 & (1) 口А & (2) \\
\hline \multirow{3}{*}{9} & $\begin{array}{c}\text { Start } \\
\text { of Cycle }\end{array}$ & $\begin{array}{l}\text { (3) } \sqrt{3} 3 \\
\text { (4) } \\
4\end{array}$ & & & & (2) & & & & & \\
\hline & \begin{tabular}{|c|} 
End \\
of Cycle
\end{tabular} & & $\begin{array}{l}\text { (3) } 3 \\
\text { (4) } 4\end{array}$ & & & & (2) & & & & \\
\hline & $\begin{array}{c}\text { Disposition } \\
\text { of Rods }\end{array}$ & & & & & & & $\begin{array}{l}\text { (3) } 3 \text { 3 } \\
\text { (4) } 4\end{array}$ & & (2) & 2 \\
\hline \multirow{3}{*}{10} & $\begin{array}{c}\text { Start } \\
\text { of Cycle }\end{array}$ & & 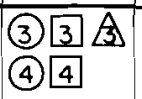 & & & 2 & & & & & \\
\hline & $\begin{array}{c}\text { End } \\
\text { of Cycle }\end{array}$ & & & $\begin{array}{l}\text { (3) } 3 \text { B } \\
\text { (4) } 4\end{array}$ & & & 2 & & & & \\
\hline & $\begin{array}{c}\text { Disposition } \\
\text { of Rods }\end{array}$ & & & & & & & (4) 4 & & (3) 3 (3) & 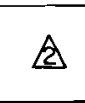 \\
\hline \multirow{3}{*}{11} & $\begin{array}{c}\text { Start } \\
\text { of Cycle }\end{array}$ & (5) 5 \& 4 & & (4) 4 & & 2 & & & & & \\
\hline & $\begin{array}{c}\text { End } \\
\text { of Cycle }\end{array}$ & & (5) 5,4 & & (4) 4 & & $\Delta$ & & & & \\
\hline & $\begin{array}{c}\text { Disposition } \\
\text { of Rods }\end{array}$ & & & & & & & & & $\begin{array}{l}\text { (4) } 4 \text { \& } \\
\text { (5) } 5 \text { A }\end{array}$ & \\
\hline
\end{tabular}

NOTES:

1. The FERTF Test Element Assembly Contains 6 Individually Replaceable Fuel Rods.

2. $24 \mathrm{Kw} / \mathrm{ft}$ is the Planned Maximum Local Linear Rod Power (Axial Peak-to-Average Power Ratio $=1.29$ )

3. (N) Represents the Nth Vibrationally Compacted $\mathrm{UO}_{2}-\mathrm{PuO} 2$ Fuel Rod in this Test Series

N Represents the $N^{\text {th }}$ Pelleted $\mathrm{UO}_{2}$-Pu02 Fuel Rod in this Test Series

$\mathbb{A}$ Represents the $N^{\text {th }}$ Vibrationally Compacted $\mathrm{UO}_{2}$ Fuel Rod in this Test Series

4. Each Irradiation Cycle is Assumed to be 25 Operating Days.

5. Each Irradiation Cycle is Assumed to Result in an Incremental Burnup of 1200 MWD/MTfuel at the Position of $24 \mathrm{Kw} / \mathrm{ft}$ Linear Rod Power.

6. Fuel Rods are Defected by Drilling a 1/16" Diameter Hole Through the $\mathrm{Zr}-2$ Cladding at the Position of $24 \mathrm{Kw} / \mathrm{ft}$ Linear Rod Power. 
The third series of tests (Table V) will be performed at a maximum rod power of approximately $28 \mathrm{~kW} / \mathrm{ft}$, which will produce significant fuel melting in both the vibrationally compacted powder rods and the pelletcontaining fuel rods.

After completion of the $28 \mathrm{~kW} / \mathrm{ft}$ test series, a defect test on a high burnup (approximately 10,000 $\mathrm{MWd} / \mathrm{MT}_{\text {fuel }}$ ) vibrationally compacted $\mathrm{UO}_{2}-\mathrm{PuO}_{2}$ rod, removed from the PRTR core, will be performed in the FERTF. This test, designed to investigate the effects of burnup on defect behavior, will be conducted at a maximum rod power in the range of 20 to $24 \mathrm{~kW} / \mathrm{ft}$.

Specific fuel rod exchanges between the FERTF and core positions will be required to achieve the objectives of the fuel testing program. It is planned to irradiate a special FERTF test element in a fringe position of the PRTR core to supply high burnup rods for experiments in the FERTF. Other rods may be removed from 19-rod cluster elements in core positions for FERTF experiments. The FERTF test element in the periphery of the core may also be used to accept fuel rods from the FERTF for continued irradiation. Program needs may dictate that the FERTF test element irradiated in the fringe contain rods of different plutonium compositions simultaneously.

Besides the three test series outlined, short-term irradiations consisting of one to two days exposure in the FERTF are planned (schedule permiting). These short-term irradiations, which will take place during the 24 or $28 \mathrm{~kW} / \mathrm{ft}$ test series, will be part of a study to investigate the reactivity changes caused by molten fuel operation per se. The reactivity of vibrationally compacted and pellet-containing fuel rods will be measured in the PRCF prior to irradiation in the PRTR core. After exposure in the PRTR core under nonmolten conditions, the reactivity characteristics will again be determined in the PRCF. After the second reactivity measurement in PRCF, the fuel rods will be irradiated in the FERTF for short periods of time under molten core conditions, and possible reactivity changes caused by molten fuel operation will be determined by subsequent 


\begin{tabular}{|c|c|c|c|c|c|c|c|c|c|c|c|}
\hline \multirow[b]{2}{*}{$\begin{array}{l}\text { Cycle } \\
\text { No. }\end{array}$} & \multirow[b]{2}{*}{ Event } & \multicolumn{6}{|c|}{ Approximate Fuel Rod Burnup Status, MWD/MT fuel } & \multirow{2}{*}{$\begin{array}{l}\text { Retained } \\
\text { in Test } \\
\text { Assembly } \\
\text { for use in } \\
\text { Next Cycle }\end{array}$} & \multirow{2}{*}{\begin{tabular}{|l|} 
Placed in \\
Storage \\
Basin for \\
Future \\
Use
\end{tabular}} & \multirow{2}{*}{\begin{tabular}{|l|} 
Transferred \\
to Radiomet \\
for Post- \\
Irradiation \\
Examination
\end{tabular}} & \multirow[b]{2}{*}{$\begin{array}{l}\text { Drill } \\
\text { Defect } \\
\text { Hole }\end{array}$} \\
\hline & & Unirrad. & 1400 & 2800 & 4200 & \begin{tabular}{|l|}
1400 \\
at Time \\
of \\
Defecting
\end{tabular} & $\begin{array}{l}2800 \\
(1400 \\
\text { Post- } \\
\text { Defecting) }\end{array}$ & & & & \\
\hline \multirow{3}{*}{12} & $\begin{array}{c}\text { Start } \\
\text { of Cycle }\end{array}$ & $\begin{array}{l}\text { (1) } 10 \\
\text { (2) } 201\end{array}$ & & & & & & & & & \\
\hline & $\begin{array}{c}\text { End } \\
\text { of Cycle }\end{array}$ & & $\begin{array}{l}\text { (1) } 10 \\
\text { (2) } 2 \Delta \\
\end{array}$ & & & & & & & & \\
\hline & $\begin{array}{l}\text { Disposition } \\
\text { of Rods }\end{array}$ & & & & & & & & 212 & (1) $10 \Delta$ & (2) \\
\hline \multirow{3}{*}{13} & $\begin{array}{c}\text { Start } \\
\text { of Cycle }\end{array}$ & $\begin{array}{l}\text { (3) } 3 \text { B } \\
\text { (4) } 4\end{array}$ & & & & (2) & & & & & \\
\hline & $\begin{array}{l}\text { End } \\
\text { of Cycle }\end{array}$ & & $\begin{array}{l}\text { (3) } 383 \\
\text { (4) } 4\end{array}$ & & & & (2) & & & & \\
\hline & $\begin{array}{c}\text { Disposition } \\
\text { of Rods }\end{array}$ & & & & & & & $\begin{array}{l}\text { (3) } 3 \\
\text { (4) } \\
4\end{array}$ & & (2) & 2 \\
\hline \multirow{3}{*}{14} & $\begin{array}{c}\text { Start } \\
\text { of Cycle }\end{array}$ & & $\begin{array}{l}\text { (3) } 3 \text { B } \\
\text { (4) } 4\end{array}$ & & & 2 & & & & & \\
\hline & $\begin{array}{c}\text { End } \\
\text { of Cycle }\end{array}$ & & & \begin{tabular}{|l} 
(3) 3 B \\
(4) 4
\end{tabular} & & & 2 & & & & \\
\hline & $\begin{array}{c}\text { Disposition } \\
\text { of Rods }\end{array}$ & & & & & & & (4) 4 & & (3) $\begin{array}{c}3 \\
2\end{array}$ & 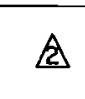 \\
\hline \multirow{3}{*}{15} & $\begin{array}{c}\text { Start } \\
\text { of Cycle }\end{array}$ & (5) 544 & & (4) 4 & & 2 & & & & & \\
\hline & $\begin{array}{c}\text { End } \\
\text { of Cycle }\end{array}$ & & (5) 54 & & (4) 4 & & 2 & & & & \\
\hline & $\begin{array}{c}\text { Disposition } \\
\text { of Rods }\end{array}$ & & & & & & & & & $\begin{array}{l}\text { (4) } 4 \mathrm{~A} \\
\text { (5) } 5.4\end{array}$ & \\
\hline
\end{tabular}

NOTES:

1. The FERTF Test Element Assembly Contains 6 Individually Replaceable Fuel Rods.

2. $28 \mathrm{Kw} / \mathrm{ft}$ is the Planned Maximum Local Linear Rod Power (Axial Peak-to-Average Power Ratio $=1.29$ )

3. (N) Represents the $\mathrm{N}^{\text {th }}$ Vibrationally Compacted $\mathrm{UO}_{2}-\mathrm{PuO} 2$ Fuel Rod in this Test Series

N] Represents the $\mathrm{N}^{\text {th }}$ Pelleted $\mathrm{UO}_{2}-\mathrm{PuO}_{2}$ Fuel Rod in this Test Series

Represents the $\mathrm{N}^{\text {th }}$ Vibrationally Compacted $\mathrm{UO}_{2}$ Fuel Rod in this Test Series

4. Each Irradiation Cycle is Assumed to be 25 Operating Days.

5. Each Irradiation Cycle is Assumed to Result in an Incremental Burnup of $1400 \mathrm{MWD} / \mathrm{MT}$ fuel at the Position of $28 \mathrm{Kw} / \mathrm{ft}$ Linear Rod Power.

6. Fuel Rods are Defected by Drilling a 1/16" Diameter Hole Through the Zr-2 Cladding at the Position of $28 \mathrm{Kw} / \mathrm{ft}$ Linear Rod Power. 
low temperature measurements in the PRCF. Reactivity measurements will provide an indication of the effects of possible plutonium migration or segregation from the liquid phase, fission product migration, fission gas release, etc., that might occur.

Some fuel rods, instrumented to measure internal gas pressure and plenum gas temperature during operation, will be irradiated in PRTR core positions during the Batch Core Experiment. These experiments will provide important information related to fuel rod design, fuel performance, and fission gas release behavior. Similar data, providing information related to defect behavior during irradiation, are of interest also for defected fuel rods. During the latter part of the FERTF fuel testing program, it is planned that an instrumented, intentionally defected, $\mathrm{UO}_{2}-\mathrm{PuO}_{2}$ fuel rod will be irradiated in the FERTF under molten core conditions. 


\section{REFERENCES}

1. Program Analysis and Plans, Plutonium Utilization Program, FY 1967 through 1970, compiled by F. G. Dawson, Program Leader, BNWL298, July 1, 1966.

2. J. R. Worden, W. L. Purcell, and L. C. Schmid, Physics Experiment High Power Density Core of the PRTR, BNWL-221, January 1966.

3. N. G. Wittenbrock, P. C. Walkup, and J. K. Anderson, Plutonium Recycle Test Reactor. Final Safeguards Analysis, HW-61236 SUP1. General Electric Company, Richland, Washington, October 1, 1959.

4. P. C. Walkup, PRTR Fuel Element Rupture Test Facility Capabilities and Project History, BNWL-40, March, 1965.

5. J. K. Anderson and W. K. Winegardner, Plutonium Recycle Critical Facility Final Safeguards Analysis, HW-69168, General Electric Company, Richland, Washington, February 1962. 


\section{DISTRIBUTION}

No. Of

Copies

2

Argonne National Laboratory

R. Avery

R. E. Macherey

1 Atomic Energy Commission Toronto Technical Representative

D. G. Boyer

4 Atomic Energy Commission, Washington Division of Reactor Development and Technology
A. Giambusso
R. M. Grube
M. Shaw
E. E. Sinclair

1 Atomic Energy of Canada Limited

Chalk River, Canada

M. N. Hudson

$1 \quad$ Battelle Memorial Institute

D. L. Morrison

1 Combustion Engineering

W. P. Chernock

3 Division of Technical Information Extension

2 Douglas United Nuclear

C. D. Harrington

C. W. Kuhlman
No. Of

Copies

2 Edison Electric Institute 750 Third Ave

New York, N. Y. 10017

H. A. Wagner, Chairman EEI Committee on Nuclear Fuels

1 General Electric Company, APED

R. B. Richards

4 General Electric Company, NTD Pleasanton

L. P. Bupp

J. G. Carver

E. A. Evans

A. B. Greninger

2 General Electric Company, APO

R. E. Skavdah1

E. L. Zebroski

$1 \quad$ Nuclear Materials and Equipment Corporation

C. S. Caldwell

5 Richland Operations Office

L. R. Lucas

P. G. Holsted

C. L. Robinson

R. K. Sharp

Tech Information Library

1 United Nuclear Corporation

C. Graves 


\section{DISTRIBUTION (contd)}

No. Of

Copies

4 Westinghouse Electric Corp.

R. J. Allio

H. Graves

W. H. Ray

J. H. Wright

F. W. Albaugh

W. J. Bailey

J. W. Batch

J. B. Burnham

S. H. Bush

J. J. Cadwell

P. D. Cohn

G. M. Dalen

F. G. Dawson

D. R. Doman

D. R. de Halas $(10)$

R. F. Dickerson

R. L. Dillon

E. A. Eschbach

M. D. Freshley (50)

S. L. Fawcett

J. R. Fishbaugher

J. C. Fox

S. Goldsmith

R. L. Gulley

W. L. Hampson

H. A. Hanthorn

H. Harty

R. E. Heineman

P. L. Hofmann

G. R. Horn

R. L. Junkins

Battelle Northwest (contd)

J. P. Keenan

A. R. Keene

J. W. Kutcher

D. D. Lanning

W. R. Lewis

R. J. Lobsinger

J. L. Maryott

M. K. Millhollen

R. E. Nightingale

F. E. Panisko

H. M. Parker

R. S. Paul

L. T. Pedersen

L. A. Pember

A. M. Platt

R. H. Purcell

W. D. Richmond

W. E. Roake

L. C. Schmid

R. E. Sharp

R. I. Smith

D. H. Stewart

H. A. Taylor

L. D. Turner

E. E. Voiland

M. T. Walling

R. G. Wheeler

N. G. Wittenbrock

D. C. Worlton

Technical Information Files (10)

Technical Publications (2) 


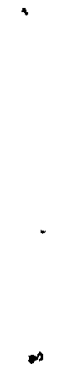

